US sea lions \section{join casualties}

Berkeley

Ir has been a bad year for seals and sea lions worldwide. While Baltic and North Sea seals are dying of viral infection (see Nature 355, 3; 1988), sea lions on the California coast are falling victim to two separate maladies, and as in the North Sea case, questions have been raised as to whether pollution is to blame.

Since June, over 100 sea lions suffering from leptospirosis have been taken to the California Marine Mammal Center outside San Francisco, and half have died. Leptospirosis is a bacterial disease that causes kidney damage and infects cattle, swine and rodents, as well as humans. It first appeared in California sea lions in 1970. Neylan Vedros, of the University of California at Berkeley School of Public Health, traced the 1970 outbreak to the rodent population in island rookeries where the sea lions raise their young. $\mathrm{He}$ says the disease is probably continually present in the sea lion population at subclinical levels, causing periodic outbreaks when population immunity drops sufficiently. A 1984 outbreak killed about a tenth of the population, and some environmentalists question whether this year's outbreak, because it follows closely on the heels of the last, indicates a pollutioninduced weakening of the animals' immune defences. Vedros, an immunologist, says there is no evidence of that.

In the past few months, a second illness characterized by severe seizures has appeared in sea lions off the central California coast, near San Luis Obispo. Mary Jane Schramm, of the California Marine Mammal Center, says 28 ailing sea lions and two fur seals have been brought to the centre, and eight have died. Because the outbreak has been localized to a region of the coast where there is oil exploration, in addition to other industry, the centre has asked for help from the US Environmental Protection Agency (EPA) in investigating whether a pollutant may be to blame. The symptoms are consistent with heavy metal poisoning, says Vedros, who is testing animals for heavy metals as well as for signs of bacterial or viral infection.

Peigin Barrett, director of the Marine Mammal Center, says that several years ago there was a similar seizure illness affecting male sea lions off the northern California coast, but an investigation by EPA specialists and the Marine Mammal Center could not find its cause

Because of their position at the top of the food chain, seals and sea lions may be sensitive indicators of toxin accumulation in the fish they eat, and environmental groups are poised to point the finger at pollution.

\title{
Paris AIDS retrovirus conference
}

Paris

"THIS is the year of realism" in AIDS research, said Maxime Schwartz at the third 'Cent Gardes' meeting on retroviruses of human AIDS organized by Pasteur Vaccins and the Fondation Mérieux near Paris last week. While a panel of leading researchers painted an image of optimism for the press, albeit qualified by the lack of any real success in the quest for a vaccine, it was clear to most of the 300 invited participants that nothing substantially new had happened since last year.

Jeanne-Marie Leconte, president of Pasteur Vaccins, contrasted the disappointingly slow progress in the search for a vaccine, given the extraordinary initial progress in understanding the human immunodeficiency virus (HIV), with Pasteur's preparation of a rabies vaccine within two years. It took another 80 years before the virus was isolated and a further 24 years before its genome was sequenced.

Not surprisingly, many papers concentrated on the small strategic handhold so far available on HIV - the affinity of the virus envelope glycoprotein gp120 for CD4 receptor sites on some host cell surfaces. But attempts so far to immunize primates with purified gp120 have failed to protect the animals from infection. Attempts to use soluble CD4 analogues to inhibit viral binding (see Nature 334, 557; 1988) are also meeting obstacles. Apart from the very short half-life of CD4 (less than 2 hours in humans, according to Daniel Capon of Genentech), and the ability of HIV mutants to sidestep this receptor, Richard Axel of the Institute of Cancer Research at Columbia University is worried that the immunoglobulin model for CD4 analogues may turn out to be inappropriate. "If this analogy is wrong, then all we think may be wrong", said Axel.

The meeting's organizers deliberately excluded epidemiological studies and also decided not to include reports on public health measures. Human clinical trials of therapeutic agents were also little touched upon. But Donald Abrams, of San Francisco General Hospital, reported on trials using oral dextran sulphate with AIDS patients. Abrams confirmed earlier fears (see Nature 334, 369; 1988) that the US Food and Drug Administration's deregulation of unapproved imported drugs with known therapeutic use against AIDS would handicap attempts to carry out controlled clinical trials. Japanese colleagues, he said, were likely to stop collaborating if use of dextran sulphate could no longer be controlled.

Peter Coles

\section{Five years of French AIDS coverage}

Paris

NEWSPAPER coverage of AIDS has revolutionized the public image of the scientist, says a report* from the French Centre for Medical Research and Social Sciences (CERMES). But if the press has also helped to transform the disease from 'mystery gay cancer' in 1982 to a 'social phenomenon' today, the authors argue that we can expect a future waning of media interest if the disease is seen as affecting mostly disinherited members of society and populations of poor countries.

The report analyses the coverage of AIDS in six national French daily newspapers, from the first article in January 1982, up until the second international

\section{Franco-Australian research agreement}

\section{Paris}

THE French Research Minister, Hubert Curien, and his Australian counterpart, John Button, last week signed an agreement to cooperate in science and technology. This move marks an attempt to restore political detente between the two countries, at loggerheads over French nuclear testing in the South Pacific as well as over the sinking of the Greenpeace ship, Rainbow Warrior by French agents. Peter Coles conference on AIDS in Paris in 1986 "More than on any other occasion", says the report, "during the history of AIDS, research has had news value." Reporting of the dispute between US and French laboratories over patent rights to the AIDS antibody test kit showed that research is more than a matter of intellectual prestige. Political and economic issues are also involved. Researchers were not slow to exploit this advantage, complaining to the press of underfunding.

Because the number of cases is continually growing, statistics in themselves always have news value. But if the press has helped to create notions of risk, global responsibility and the emergence of AIDS as a 'social reality', the report finds that the daily newspapers have also helped to engender fear, albeit while trying to inform. This has been exacerbated by the absence of effective therapies, despite the extraordinarily rapid progress in understanding of the disease.

The report suggests that the present period of intense media interest in AIDS could be followed by "rejection and lack of interest" if the disease is perceived as affecting mostly socially deprived groups and populations of "disenfranchized continents".

Peter Coles

" Herzlich and J. Pierret Une maladie mediatisée, Le SIDA duns sis quotidiens francais. CERMES-CNRS/INSERM/EHSS $19 \mathrm{~s} 8$. 